\title{
SIGNIFICANCE OF CO-OPERATION TO AGRICULTURE IN FINLAND.
}

\author{
BY \\ SEPPo Simonen.
}

Received 2. 2. 1950

1949 can be considered an anniversary in the history of Finnish Co-operation. Exactly half a century has passed since the start of the movement. In February, 1899, the possibility of introducing on Finnish soil the new form of economic collaboration learnt from abroad, Co-operation, was discussed by certain circles representative of the Finnish educated classes, and within that year words were translated into deeds. At a meeting on October 2 a new organisation covering the entire country was established and styled Pellervo, The Society For The Promotion of Co-operation Among The Agricultural Population Of Finland. This organisation, the name of which was subsequently changed to Pellervo-Seura (The Pellervo Society), made it its first task to effect the passing of a special Co-operation Act, which entered into force in Autumn 1901. Immediately afterwards The Pellervo Society was able to initiate its work proper, the establishment of co-operative societies to serve the requirements of the farmers in the various parts of the country. This work was carried on by the Society for some twenty years under the leadership of its founder, Professor Hannes GeBhard, who has been given the honorary title of the »Father of Finnish Co-operation» (16).

It is fairly easy to decide which lines of agricultural production, during the past fifty years, have been most perceptibly affected by Co-operation. There is hardly any doubt that milk and dairy economy and agricultural credits have benefitted most, relatively speaking, from Co-operation.

In the latter half of the 19th century production of grain both in overseas countries and in Russia began to grow rapidly, and before long a stream of cheap foreign grain flowed into the European countries. Finland too became a recipient, and, particularly in the late 1880's the profitability of domestic grain growing became doubtful. At the same time the possibility of placing increasing quantities of butter on the English market both necessitated and made possible a complete reversal in the trend of agricultural production in Finland. The 1890's, then, were characterised by a noticeable decline in the cultivation of bread grains, by a corresponding 
expansion in the cultivation of various fodder crops, and by the growth of cattle breeding and dairying to the principal form of agricultural production. At the turn of the century butter was the most important agricultural export, while imports fo bread grain were by this time considerable (15).

The first butter dairy, a so-called "manor-house dairy", was established in Finland in 1846 , soon followed by others established in different parts of the country (7, p. 179). In the 1890 's great diversity was the keynote of the dairy branch. Alongside the manor-house dairies there existed numerous other dairy enterprises owned by private individuals, e.g. country merchants, and in addition there were dairies operated by joint-stock companies or associations, and forms of enterprise somewhere between these had also grown up. A considerable proportion of the milk was still processed into farm-butter. As the price of butter revealed a rising tendency and as even inferior quality butter found a ready market, the dairy branch was a field for unsound competition, providing little possibility of improving the quality of the product. In the circumstances it is comprehensible that the seeds of a cooperative dairy scheme found ready soil for planting throughout the country. Only by means of co-operative dairies was it possible to obtain for milk as high a price as possible in prevailing conditions. This was soon realised by agricultural circles throughout the country, and both private and joint-stock company dairies began to give way, immediately after the turn of the century, to co-operative dairies (18, p. 174).

The great achievement of the co-operative dairy movement must still be considered the fact that it organised the foreign trade in butter. The seemingly unlimited demand for butter on the English market, and the good price level attracted a great number of private persons to start dealing in butter, professional skill and business ethics playing a subsidiary part $(8, \mathrm{p}, 162)$. On the initiative of the Pellervo Society certain co-operative dairies established, in 1905, a central business house, styled Voinvientiosuusliike Valio (The Valio Co-operative Butter Export Association) which, as its name would suggest, immediately began to export butter produced by its member dairies. In spite of stiff resistance from private butter merchants (10, p. 360-361), Valio took an annually increasing share of the butter exports, and by the years immediately preceding the First World War it held a dominating position in this branch. In this way the butter exports were placed on a firm foundation, and good business connections were established with the English and German buyers. Another of Valio's achievements is that, during Finland's Independence, cheese has become an important agricultural export, alongside butter, formerly practically exclusive (14, p. 90-103).

Together with the co-operative dairy movement, Finnish conditions were ripe for the introduction of the co-operative credit society, and there was, moreover, a grave need of this form of enterprise. At the end of the last century credit conditions in the rural districts revealed grave inadequacies. The abandoning of the centuries old production system based on the dominance of grain cultivation, and adoption of the extensive cultivation of fodder crops and, further, of dairy production, required considerable capital investments, investments which the small farms in parti- 
cular found difficult to raise. The need for capital investment in the rural districts was further added to by the fact that the landless population, which had greatly increased in number, desired farms of their own. However, it was very difficult to obtain credits for such purposes and even impossible for the smaller farmers. In the almost entire absence of agricultural credits proper, small farmers were compelled to resort to bill of exchange credits granted by commercial banks at high interest, or to turn to private money-lenders. In the latter case they ran the risk of falling into the clutches of usurers (3).

A study of economic collaboration between farmers abroad had given GEBHARD a very high opinion of co-operative credit societies operated according to RAIFFEISEN's principles $\left.{ }^{1}\right)$. Endorsing his view, the Pellervo Society, at the turn of the century, took measures towards the creation of a network of co-operative credit societies in the country. The first phase of this work was the establishment of the Osuuskauppojen Keskuslainarahasto (Central Bank for Co-operative Agricultural Credit Societies, abbreviated OKO) in 1902, difficult though this proved in the face of the resistance from the Russian overlords (13, p. 123-127). Within that year the first society started its activities, soon succeeded by others. In 1904 the societies enjoying credits from the Central Bank numbered 69, in 1906148 and in 1908 268. In the lastmentioned year the credits granted farmers through the societies totalled $3,527,650$ mks, a considerable sum for the then conditions. In this way credit conditions in the rural districts developed along sounder lines, thanks to the co-operative credit societies movement, and the farmers could be saved from usurers' bonds.

The significance to agriculture of the third principal form of Co-operation, the co-operative retail shops, is not easy to define, even in general terms. One source of difficulty is uncertainty as regards its productive character, whether the co-operative retail shop movement, in the main, should be counted amcng producers' or consumers' co-operative activities (19, p. 188-194). This has bcen the subject of much dispute in Finland in the course of the years, and it is a question that cannot be considered as solved yet. GEBHARD regarded co-operative shops as purely consumers' activities, so much so that he was against including them in the sphere of the Pellervo Society. ${ }^{2}$ ) This viewpoint subsequently underwent a complete reversal. Since 1915 the Pellervo Society has recognised co-operative retail societies, in which the membership majority is constituted by farmers, as agricultural co-operative societies of equal standing to co-operative dairies and credit societies (1, p. 271-277). As a result of the severe policy struggles in 1916 (11, p. 137-218). Suomen Osuuskauppojen Keskuskunta (The Finnish Co-operative Wholesale Society, abbreciated SOK),

1 Gebhard's ideas are illustrated by following (5, p. 373): "They (farmers' co-operative credit societies) can also be compared to rain which, after a lengthy, disastrous drought stimulates the growth of vegetation and makes it luxurious. Dead vegetation is small-farming stricken with desolation and the shortage of money, incapable of adapting itself to new conditions without Co-operation, incapable of acquiring new supplies for a new prosperity of cultivation."

2 Instead of co-operative retail societies, Gebhard recommended to farmers special co-operative societies for the purchase of agricultural requisites and sale of agricultural products( 6, p. 371). A number of them were, in fact, established, but were unsuccessful. 
the central business established in 1904, became the wholesale association for cooperative stores operated by farmers, and in this capacity it is a present-day member of the Pellervo Society. The co-operative retail stores in which consumers are in the majority have a wholesale association of their own, Osuustukkukauppa (The Co-operative Wholesale Corporation, abbreviated OTK), established in 1917. Inaddition it may be mentioned that the co-operative retail stores of the Swedish speaking population in the South of Finland and along the coast of the Gulf of Bothnia have grouped themselves around a central association of their own, Keskusosuuskunta Labor (The Central Co-operative Society Labor). This association was established in 1897, although it assumed its co-operative association form only in 1906 (23, p. $11-23$ ).

The productive character of the SOK co-operatives is indicated by the fact that they carry on very extensive trade in agricultural products and requisites. For instance the total turnover of these stores in 1948 amounted to 36,955 million marks. The sale of agricultural products totalled 6,540 millions, and of agricultural requisites 5,753 millions. Of the total turnover the proportion of trade in agricultural commodities was thus exactly one-third, a ratio that has, in general, prevailed earlier too. It is noteworthy that the sales totals of agricultural products have exceeded the corresponding sums for agricultural requisites, another point emphasising the productive character of co-operative retail societies. The co-operative retail societies own certain production plants, e.g. a total of 20 flour mills and a few small slaughterhouses. The central association SOK runs four big flour mills.

The productive nature of the SOK retail societies is further illustrated by the study of the other central businesses of these shops. Development has resulted in the retail societies forming three central associations apart from SOK, and these three are purely agricultural. On the initiative of the Pellervo Society, Keskusosuusliike Hankkija (The Hankkija Central Agricultural Supply Society) was established in 1905, originally to serve as a central association for special co-operative societies dealing in agricultural products and requisites. But as the co-operative societies of this nature established in the country were but few in number, Hankkija was compelled, early in the 1910 's, to look for an entirely new distributive organisation. Such was found in the co-operative retail societies, and the retail societies controlled by farmers, together with the co-operative dairies, soon constituted the membership of Hankkija $(20$, p. $72-87)$. Hankkija sells requisites through its retail societies to farmers, primarily fertilisers, concentrated cattle feedstuffs, machines and seed, and collects through them the products of the farms. Many of the considerable rural retail societies now have a special department to take care of this activity.

In the 1920's the retail societies began to take an interest in the trade in cattle raised for slaughtering and in meat, and acquired membership in Karjakunta r.l. (The Central Co-operative Livestock Society), established in 1918. In the 1930's there was a split in this central association in that the original members, the provincial co-operative slaughter-houses, withdrew from Karjakunta and set up for themselves a new central association styled Tuottajain Lihakeskuskunta (The Producers' Cetnral Meat Co-operative Society). Karjakunta, with its slaughterhouses and meat 
processing plants, thus remained in sole control of the co-operative retail societies, which at the same time were compelled to intensify their activity in collecting cattle for slaughter (21, p. 23-30). A fourth central association formed by the farmers' retail societies is Vientikunta Muna (The Muna Central Co-operative Egg Export Society), originally established in 1921, to serve as the central association for cooperative sellers of eggs. Since 1933 co-operative retail societies have been admitted to membership of Muna, and during the recent war, when the activities of the special co-operatives had been nullified due to the reduced production of eggs, Muna in its entirety went over to the running of retail societies (22, p. 20-23).

Although the co-operative retail societies grouped around OTK claim to belong to pure consumers' co-operatives, they do, to a limited extent, also trade in agricultural commodities. These societies and their central association control certain production plants, such as 6 dairies, 17 flour mills, 6 slaughter-houses, 5 sausage factories and several estates, piggeries and vegetable gardens. The total production value of these plants in 1948 amounted to $3,045.5$ million marks, or to $10.8 \%$ of the total sales of OTK and its retail societies.

As is apparent from the foregoing, certain special co-operative societies of a purely productive character have had to sail against the wind, and some have even been compelled to suspend activities altogether ${ }^{1}$ ) In spite of the co-operative slaughter-house movement in Germany having proved a complete disappointment - it even caused great economic losses to farmers (4, p. 326) - a few special co-operative societies of this character were, nevertheless, established in Finland early in this century, and in 1918 they even got Karjakunta, as mentioned above, to act as their central association. In the 1920's several co-operative slaughter-houses went bankrupt, and in the following decade those remaining, and a few new slaughter-houses, encountered competition from the farmers' co-operative retail societies. This was the start of the policy fight, a fight still going on and known as the "cattle quarrel", between the organisations of the co-operative slaughter-houses and the co-operative retail societies. Owing to this battle, the benefits received by cattle breeders from co-operative activities have remained smaller than expected, and, in addition, it has very adversely affected the authority of the co-operative movement group supporting the Pellervo Society (12, p. 193-195). It is also remarkable that there is still a lively participation by private enterprișe in the trade in cattle for slaughter and in meat.

Already in the early years of the co-operative movement it was clearly apparent that of the numerous forms of co-operative societies tried out abroad, co-operative dairies, credit societies and retail societies were natural to Finnish conditions, and they soon developed into the three principal branches of the movement. They were also the main targets of the instruction and tuition work carried out by the Pellervo Society. Nevertheless the objective adopted early on was to extend the economic co-operation of farmers to all the branches in which development had been slow,

1 Besides Co-operation in gardening (2, p. 90-92), Co-operative activities among fishermen in Finland have not come up to expectations. 
Table 1. Co-operative Activities

Active Co-operative Societies, their Membership and turnover in

\begin{tabular}{|c|c|c|c|c|c|c|c|c|c|c|}
\hline \multicolumn{3}{|c|}{ Credit Societies } & \multicolumn{3}{|c|}{ Co-operative Dairies } & \multicolumn{5}{|c|}{ Retail Societies } \\
\hline $\begin{array}{l}\text { Num- } \\
\text { ber }\end{array}$ & $\begin{array}{l}\text { Member- } \\
\text { ship }\end{array}$ & $\begin{array}{c}\text { Loan } \\
\text { claims } \\
\text { mill. mk }\end{array}$ & $\begin{array}{c}\text { Num- } \\
\text { ber }\end{array}$ & $\begin{array}{l}\text { Member- } \\
\text { ship }\end{array}$ & \begin{tabular}{|c|} 
Sales \\
mill. \\
mk.
\end{tabular} & $\begin{array}{c}\text { Num- } \\
\text { ber }\end{array}$ & $\begin{array}{l}\text { Number } \\
\text { of sales } \\
\text { points }\end{array}$ & $\begin{array}{l}\text { Member- } \\
\text { ship }\end{array}$ & $\begin{array}{l}\text { Sales } \\
\text { mill. } \\
\text { mk. }\end{array}$ & $\begin{array}{l}\text { Sales of } \\
\text { agric. } \\
\text { prod. } \%\end{array}$ \\
\hline 1) 66 & 2200 & 0.3 & 2) 118 & 33200 & 6.1 & 79 & & 14000 & 5 & \\
\hline 268 & 12000 & 4.3 & 319 & 40000 & 25 & 403 & 753 & 80000 & 42 & \\
\hline 432 & 21000 & 5 & 374 & 47000 & 39 & 423 & 817 & 94000 & 67 & \\
\hline 594 & 29000 & 13 & 434 & 54000 & 157 & 543 & 1541 & 220000 & 545 & \\
\hline 935 & 54000 & 155 & 522 & 70000 & 570 & 467 & 1878 & 179000 & 1135 & 17.4 \\
\hline 1398 & 128000 & 859 & 673 & 76000 & 858 & 425 & 2280 & 207000 & 1686 & 25.9 \\
\hline 1368 & 142000 & 1312 & 691 & 77000 & 742 & 418 & 2686 & 238000 & 1699 & 28.2 \\
\hline 1148 & 152000 & 1954 & 650 & 72000 & 1230 & 407 & 3324 & 291000 & 2974 & 33.9 \\
\hline 1010 & 165000 & 2755 & 537 & 70000 & 2093 & 394 & 3430 & 370000 & 5783 & 34.7 \\
\hline 890 & 194000 & 8442 & 506 & 69000 & 4480 & 370 & 3507 & 417000 & 16872 & 32.8 \\
\hline 841 & 205000 & 13082 & 466 & 69000 & 6543 & 372 & 3670 & 445000 & 23591 & 38.4 \\
\hline 767 & 211000 & 20600 & 463 & 10000 & 12000 & 374 & 3570 & 459000 & 36955 & 33.3 \\
\hline
\end{tabular}

or in which an evidently unsatisfactory state of affairs existed. This resulted in the group of so-called mother co-operatives» or "small co-operatives» (17), which in spite of its numbers - in 1948 they totalled 3,100 - has continued to hold a very modest position compared with the three main groups. This group of small co-operatives includes a miscellany of co-operative enterprises. As an example may be mentioned the agricultural machine co-operatives, the first of which was established in 1902. In a typical small-farming country like Finland the use of machines encounters difficulties, and attempts have been made to solve this problem by purchasing machines, primarily threshing machines, for the joint use of the farmers of one village. Apart from the enthusiasm of the early years, these machine co-operatives have had little success, and of late have had little significance at all.

In the course of years special co-operatives have been established here and there in the country for the production of moss litter, the establishment of flour mills and sawmills, the building of small-scale electric power stations, the installation of a telephone network, etc. All such enterprises, however, have remained on a very modest scale. Their significance to agricultural production cannot be shown in any way, particularly as there is no certainty as to which of the small co-operatives are active and which are mere entries in the Trade Register. It is characteristic that although the small co-operatives are estimated at being over 3,000 in number, the Pellervo Society employed a single instructor to take charge of their instruction. The group of small co-operatives is also considered to include the breeding-bull co-operatives, societies of cattle-breeders, working on co-operative lines. The work of breeding-bull co-operatives has yielded good results, and they still hold a certain position in cattle improvement activities.

$\left.{ }^{1}\right)$ In $1903-1905$

2) In $1902-1905$ 
Controlled by the Pellevvo Society.

millions of marks, as an average per year, by five-year periods.

\begin{tabular}{|c|c|c|c|c|c|c|c|c|c|}
\hline \multicolumn{3}{|c|}{ Co-operative Slaughter-Houses } & \multicolumn{3}{|c|}{ Other Co-op. Societies. } & \multicolumn{3}{|c|}{ Total } & \\
\hline $\begin{array}{l}\text { Num- } \\
\text { ber }\end{array}$ & $\begin{array}{l}\text { Member- } \\
\text { ship }\end{array}$ & $\begin{array}{c}\text { Sales } \\
\text { mill. } \\
\text { mk. }\end{array}$ & $\begin{array}{l}\text { Num- } \\
\text { ber }\end{array}$ & $\begin{array}{l}\text { Member- } \\
\text { ship }\end{array}$ & $\begin{array}{c}\text { Sales } \\
\text { mill. } \\
\text { mk. }\end{array}$ & $\begin{array}{c}\text { Num- } \\
\text { ber }\end{array}$ & $\begin{array}{l}\text { Member- } \\
\text { ship }\end{array}$ & $\begin{array}{l}\text { Sales mill. } \\
\text { mk. }\end{array}$ & \\
\hline & & & 32 & 1240 & 3.2 & 295 & 27640 & 14.6 & $1901-05$ \\
\hline 3) 2 & 500 & 0.1 & 502 & 27600 & 13.3 & 1494 & 153100 & 84.7 & $1906-10$ \\
\hline 5 & 1800 & 1.5 & 856 & 41500 & 17.5 & 2090 & 198300 & 130 & $1911-15$ \\
\hline 12 & 7000 & 73 & 1105 & - & - & 2688 & 303000 & 788 & $1916-20$ \\
\hline 13 & 6000 & 126 & 1576 & - & - & 3513 & 287600 & 1986 & $1921-25$ \\
\hline 12 & - & - & 2278 & 66000 & 168 & 4786 & 471000 & 3571 & $1926-30$ \\
\hline 10 & 6000 & 114 & 2834 & 84000 & 136 & 5321 & 546000 & 4003 & $1931-35$ \\
\hline 10 & 8000 & 308 & 3223 & 94000 & 161 & 5438 & 622000 & 6627 & $1936-40$ \\
\hline 11 & 17000 & 690 & 2987 & 98000 & 155 & 4939 & 722000 & 11476 & $1941-45$ \\
\hline 11 & 28000 & 1525 & 2777 & 116000 & 352 & 4554 & 825000 & 31671 & 1946 \\
\hline 11 & 33000 & 4217 & 3112 & 132000 & 664 & 4802 & 884000 & 48097 & 1947 \\
\hline 11 & 45000 & 6776 & 3100 & 132000 & 800 & 4715 & 916000 & 77136 & 1948 \\
\hline
\end{tabular}

To what extent has the development of Finnish agriculture in the past 50 years benefitted from the co-operative movement? No concrete figures or series of statistical data can be given to illustrate the answer to this question. The growth of agricultural production and its spread to include new branches, during the period of Finnish Independence, can well be indicated in several different ways, and a number of statistical data on the question are available from the preceding period as well. It is known, for instance, that the average yields per hectare of the most important crops were doubled in the 1920's and 1930's, that self-sufficiency in bread grains, only approx. $40 \%$ in $1911-1913$, amounted to $70.7 \%$ in the harvest period 1931-1932, being $95 \%$ in 1938 - 1939, etc. Agricultural production, however, is the joint result of so many factors that the contribution of one special factor such as co-operative activities cannot be assessed even summarily in any branch of production. A study of several aspects, nevertheless, gives some idea of the contribution of the co-operative movement to recent development in agriculture.

Conclusions can be drawn, for example, from the number of active co-operative societies coming within the sphere of the Pellervo Society, and consequently within that of agricultural co-operative activities, from their membership and turnover. The table 1 supplies information on these items from the period 1901-1945, as averages for five-year periods, as well as separate figures for 1946, 1947 and 1948.

Increase in number and membership, and also in total sales, has thus generally been very considerable and regular. The information on the 1940's is not immediately comparable, for very many different co-operative societies worked in Karelian territory, ceded to the Soviet Union in 1940 and again in 1944, and only some of them continued to function after their evacuation to the remaining Finnish territory. Is must also be noted that $\mathrm{OKO}$ has recently adopted the policy of amalgamating

$\left.{ }^{3}\right)$ In $1909-1910$ 
co-operative credit societies, too small and too closely crowded together, into bigger, active societies. This explains the fact that, although the total number of credit societies has recently declined, their membership has nevertheless grown. Mergers have, to a smaller extent, also taken place in co-operative dairies and retail societies.

The total number of co-operative societies working for the benefit of farmers in Finland in 1948 amounted to 4,715. Their membership totalled 916,000, and their total sales amounted to 75,616 million marks. The significance of these figures in Finnish conditions is more readily appreciated if they are set against the total agricultural population. The most recent official figures available date from 1940, when. the agricultural population was estimated as numbering 1,901,200. During the last ten years the population in Finland has increased, but as, on the other hand, the relative importance of agriculture has distinctly declined, the error will not be great if the present agricultural population is estimated as being roughly the same as in 1940. Co-operative society membership would thus include nearly half the agricultural population, more accurately $48.2 \%$. This, in fact, cannot be taken as correct, as one and the same person is often a member of two or even more co-operative societies. Unfortunately there is no statistical information available to illustrate this point. The large membership of co-operative societies, however, justifies the conclusion that practically every family which obtains its livelihood from agriculture, through one of its members - usually the head of the family - participates in the co-operative movement. The form of co-operative society prominent in each case depends on local conditions. However, it can be said that the network of co-operative retail societies in particular is very evenly spread throughout the country, including the out-of-the-way districts of East and North Finland. Co-operative dairies and credit societies are also encountered in the different parts of the country. With special co-operative societies grouping on a territorial basis is apparent; moss litter co-operatives, for instance have gained a foothold in those southern and southwestern communes where particular attention is paid to the development of cattle-breeding and the careful treatment of manure.

The map on the right below gives some idea of the distribution of co-operative societies in the different parts of the country.

The significance of the co-operative movement to agriculture is further reflected in the position that the leading co-operative societies, the central co-operative associations, have attained in Finland's economic life. The four biggest central co-operative associations, OKO, SOK, Hankkija and Valio, experienced many difficulties at the beginning of the century - it even seemed doubtful whether Hankkija could survive at all. But as the number of local co-operative societies increased and ever greater circles of farmers joined the co-operative movement, the position of the central associations stabilised itself, and they developed rapidly into leading enterprises in the branch. In the late 1910's the central associations, in addition to their business activities, also participated in the propagation of the co-operative idea, and this development soon led to their taking independent charge of the instructional work in the branch. 


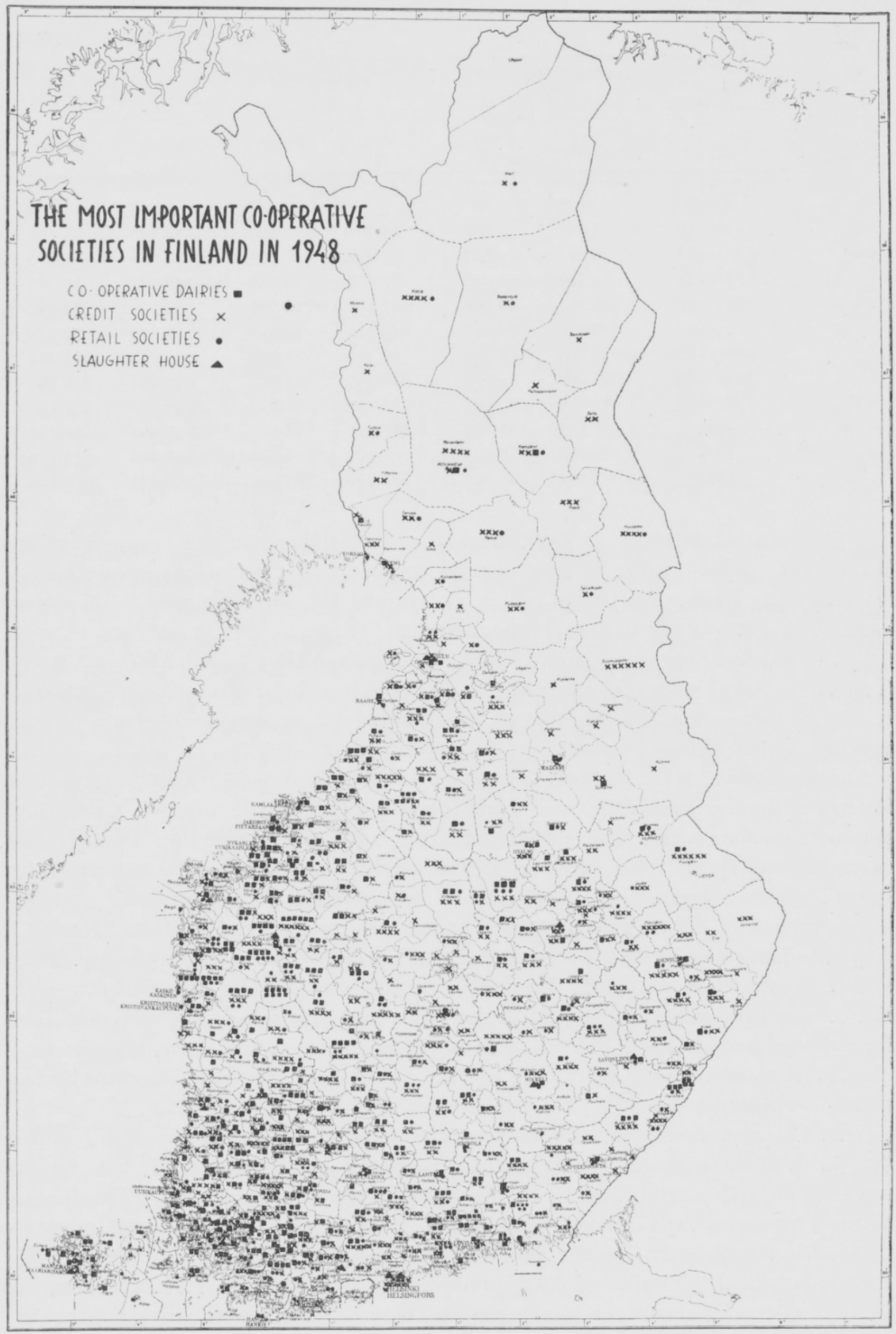


Table 2. Central Co-operative

\begin{tabular}{|c|c|c|c|c|c|c|}
\hline & \multicolumn{2}{|c|}{$\begin{array}{c}\text { Osuuskassojen Keskus } \\
\text { OKO }\end{array}$} & \multicolumn{2}{|c|}{$\begin{array}{l}\text { Voinvientiosuusliike } \\
\text { Valio }\end{array}$} & \multicolumn{2}{|c|}{$\begin{array}{l}\text { Suomen Osuuskauppojen } \\
\text { Keskuskunta SOK }\end{array}$} \\
\hline & $\begin{array}{l}\text { Loans } \\
\text { granted }\end{array}$ & $\begin{array}{c}\text { Funds }+ \\
\text { share } \\
\text { capital }\end{array}$ & Sales & Funds & Sales & Funds \\
\hline 1905 & 641 & 307 & & & 1004 & 43 \\
\hline $1906-10$ & 2707 & 333 & $11 \cdot 110$ & 296 & 10972 & 464 \\
\hline $1911-15$ & 5097 & 536 & 22602 & 778 & 23604 & 1815 \\
\hline $1916-20$ & 11754 & 1389 & 91473 & 3283 & 159941 & 10965 \\
\hline $1921-25$ & 143474 & 14206 & 434262 & 11725 & 524784 & 34292 \\
\hline $1926-30$ & 699943 & 70441 & 643140 & 20399 & 931331 & 90399 \\
\hline $1931-35$ & 968708 & 78705 & 526585 & 32551 & 941563 & 151715 \\
\hline $1936-40$ & 1003009 & 97060 & 873617 & 52752 & 1518037 & 219598 \\
\hline $1941-45$ & 1144552 & 133331 & 1412108 & 83987 & 2293220 & 301462 \\
\hline 1946 & 4255601 & 153483 & 2828485 & 114852 & 7158664 & 430225 \\
\hline 1947 & 7458652 & 156401 & 3464407 & 134133 & 9151523 & 519138 \\
\hline 1948 & 12982944 & 168489 & 10481030 & 190232 & 15862643 & 602108 \\
\hline
\end{tabular}

Information is given in table 2 on the development of the business activities of the above-mentioned four central co-operative associations, as well as of Vientikunta Muna, Karjakunta and Tuottajain Lihakeskuskunta, by five-year periods in $1901-1945$ and in 1946-1948.

In 1947 the aggregate sales of SOK, Hankkija, Valio, Muna, Karjakunta and Tuottajain Lihakeskuskunta totalled 17,780 million marks. For comparison's sake it may be mentioned that the sales of private wholesale enterprises in the same year totalled 41,761 million marks.

The influence of the co-operative movement on agricultural production is further illustrated by the percentages indicating the proportions of the different agricultural products on the market that were handled by co-operative societies. Co-operative marketing of agricultural products is studied by the Market Research Institute of the Pellervo Society, and it covers the following products: milk and dairy products, meat, eggs, wool, hides, grain, potatoes, and rough provender. The Market Research Institute has attempted to arrive at the total annual production of these products, and the percentage marketed. From this, on the basis of sales data collected from the co-operative societies, the proportion marketed through co-operative channels has been estimated. The following table on the next paga below shows the percentages of the total amounts marketed, of each of the above products, handled by farmers' co-operative societies. (Itemised calculations exist from 1935).

In the best years the farmers' own co-operative societies have thus handled $60-61 \%$ of the aggregate value of the domestic products marketed. In the marketing of milk and dairy products, the most important sales produce of Finnish agriculture, the co-operative societies hold the whip hand. In 1942 - 1945 the co-operative dairies, and partly also the SOK co-operative societies handled almost exactly three-quarters of the milk and dairy products available for sale. If, in addition, the OTK co-operative societies are included, the percentage of co-operatively marketed 
Associations $(1000 \mathrm{mk})$

\begin{tabular}{|c|c|c|c|c|c|c|c|}
\hline \multicolumn{2}{|c|}{$\begin{array}{c}\text { Keskusosuusliike } \\
\text { Hankkija }\end{array}$} & \multicolumn{2}{|c|}{$\begin{array}{l}\text { Vientikunta } \\
\text { Muna }\end{array}$} & \multicolumn{2}{|c|}{ Karjakunta } & \multicolumn{2}{|c|}{$\begin{array}{c}\text { Tuottajain Liha- } \\
\text { keskuskunta }\end{array}$} \\
\hline Sales & Funds & Sales & Funds & Sales & Funds & Sales & Funds \\
\hline 727 & 14 & & & & & & \\
\hline 2732 & 77 & & & & & & \\
\hline 6950 & 310 & & & & & & \\
\hline 83878 & 5899 & & & 2) 16609 & 484 & & \\
\hline 162397 & 8276 & $\left.{ }^{1}\right) 4697$ & 49 & 31650 & 925 & & \\
\hline 310880 & 22249 & 7076 & 170 & 67225 & 2343 & & \\
\hline 223526 & 37027 & 42040 & 1589 & 70959 & 4632 & & \\
\hline 442111 & 59416 & 76702 & 6330 & 142392 & 8819 & 34594 & 319 \\
\hline 685564 & 112918 & 29179 & 7733 & 228809 & 16749 & 81286 & 1511 \\
\hline 2127476 & 143840 & 182917 & 8573 & 500470 & 30446 & 58042 & 2573 \\
\hline 3209690 & 160749 & 372877 & 9734 & 1355236 & 35741 & 426124 & 2960 \\
\hline 5223332 & 186058 & 250550 & 10148 & 2036455 & 51903 & 724400 & 3603 \\
\hline
\end{tabular}

milk and dairy products amounts to $80-90$ of the total available for sale. For meat, too, the co-operative trade percentages are considerable, e.g. in $194860 \%$.

There are several other ways in which the influence of co-operative activities on the development of agricultural production in the present century can be illustrated, particularly as regards that of the co-operative dairies and their central association, Valio. Statistically it can be ascertained that the co-operative dairies contribution to dairy butter production continued to increase until the late 1920 's, when the percentage was 95 . In cheese production the share of co-operative dairies was"at

\begin{tabular}{|c|c|c|c|c|c|c|c|c|c|}
\hline Year & Milk & Meat & Eggs & Wool & Hides & Grain & Potatoes & $\begin{array}{c}\text { Rough } \\
\text { Provender }\end{array}$ & Averag \\
\hline & $\%$ & $\%$ & $\%$ & $\%$ & $\%$ & $\%$ & $\%$ & $\%$ & $\%$ \\
\hline 1935 & 57.9 & 41.9 & 37.1 & 5.0 & & 30.5 & 17.4 & 6.6 & 44.4 \\
\hline 1936 & 61.9 & 46.2 & 39.0 & 7.9 & & 30.0 & 17.8 & 7.2 & 47.0 \\
\hline 1937 & 59.4 & 52.1 & 43.3 & 7.4 & & 27.1 & 17.4 & 6.6 & 48.6 \\
\hline 1938 & 64.0 & 57.0 & 41.5 & 2.4 & & 31.1 & 16.4 & 9.5 & 50.1 \\
\hline 1939 & 63.8 & 64.3 & 38.8 & 5.9 & & 44.5 & 15.9 & 7.2 & 52.0 \\
\hline 1940 & 63.9 & 68.0 & 53.0 & 9.2 & & 77.0 & 13.7 & 10.1 & 54.3 \\
\hline 1941 & 66.0 & 61.1 & 35.1 & 36.3 & 36.3 & 35.5 & 25.4 & 5.9 & 46.1 \\
\hline 1942 & 75.0 & 67.7 & 40.0 & 49.2 & 38.6 & 54.4 & 34.2 & 6.6 & 54.8 \\
\hline 1943 & $7 b .4$ & 60.9 & 60.0 & 56.7 & 40.3 & 50.6 & 53.5 & 15.1 & 61.2 \\
\hline 1944 & 76.7 & 59.3 & 60.0 & 51.5 & 40.1 & 51.2 & 41.6 & 13.9 & 60.2 \\
\hline 1945 & 76.8 & 62.5 & 33.3 & 49.0 & 36.1 & 47.0 & 38.1 & 12.8 & 58.9 \\
\hline $194 \mathrm{C}$ & 65.0 & 56.6 & 65.4 & 44.1 & 35.7 & 53.9 & 46.4 & 18.4 & 52.3 \\
\hline 1947 & 63.4 & 60.4 & 58.5 & 39.0 & 34.5 & 54.9 & 36.4 & 13.7 & 55.0 \\
\hline 1948 & 68.6 & 60.0 & 53.7 & 56.3 & 37.0 & 55.0 & 35.7 & 13.8 & 59.9 \\
\hline
\end{tabular}


its highest in 1935, reaching $75.3 \%$. In this connection it may be mentioned, too, that approx. $50 \%$ of the cows in Finland "milk into co-operative dairies». Exports of dairy products have taken place mainly through Valio and the central association of the co-operative dairies working in the Swedish speaking districts of the country, Centrallaget Enigheten, established in 1917. Valio's contribution to butter exports amounted to $20.9 \%$ as early as in its second year of operation, 1906. By 1912 it had risen to $52.1 \%$, in 1914 it was $81.4 \%$, and in $193493.5 \%$. If the exports by Enigheten are included, it can be said that the foreign trade in butter in the late 1930's was handled entirely by the co-operative dairy movement. In the exportation of cheese Valio and Enigheten do not dominate to the same extent as in the butter trade, though their contribution is considerable. In 1939 Valio's share of the cheese exports was $67.7 \%$. The percentage for Enigheten has varied between $10-14 \%$.

In considering the influence of the co-operative dairy movement on agriculture special emphasis must be laid on Valio's valuable work for the improvement of the quality of dairy products and the advance of their competitive capacity. At the beginning of the century the average price for Finnish butter in the markets of the most important buying country, England, was considerably lower than for Danish butter, due to its lower quality. In its very first year of activity Valio introduced the method of payment according to quality, and in consequence the average prices of Finnish and Danish butter rapidly began to approach each other. In 1907 the mean value of Valio's weekly accounting prices per 100 kilos was mk 13.87 below the corresponding mean value of Copenhagen quotations. By the next year, already, this difference had been reduced to $\mathrm{mk} 8.07$, and in 1911 it was only mk 3.46. After the First World War Valio's work for the improvement of the quality of butter was further intensified, and about 1930 another fine result of this work was that Finnish export butter attained a quality distinctly superior to the Swedish, and achieved second place in the quality statistics of all countries, coming immediately after Denmark. It is also thanks to Valio, as mentioned previously, that cheese production was got under way in the co-operative dairies, and that cheese, since Finland gained her Independence, has become an important export product alongside butter.

The influence on agriculture of the second principal form of co-operative movement in Finland, that of the credit societies can be illustrated by, for example, data on the use made of the loans granted by co-operative credit societies. As early as in 1912 , ten years after the establishment of the first credit societies, OKO endeavoured to investigate how the loans were used. The extensive inquiry carried out showed convincingly that the credit societies, thanks to the funds they could raise, had been able to increase the property of their members considerably. Their members, with the aid of society funds, had been able, by the end of 1912, to clear a total of 11,800 ha of new field, to dig $10,900 \mathrm{~km}$ of ditch, to buy 6,000 cows, 1,873 horses and 981 pigs, to build 1,331 new living houses and 2,237 cattle-sheds, to buy 814 mowing machines, 1,198 ploughs, 257 threshing machines, etc. The monetary value of the economic renovations carried out with the aid of society funds in 1902-1912 was computed to be $6,716,000$ marks. 
A similar inquiry into the use of credit society loans was pursued in 1922, and the results of this investigation, too, indicate that the societies, with the credits received from the central fund, had been able to benefit agriculture in many ways and add to its resources. Later on the central body responsible for the instruction and inspection of co-operative credit societies, Osuuskassojen Keskusliitto (Central Association of Co-operative Credit Societies) worked out annual tables on the use made of society loans granted for various purposes. The inspection of such loans in 1948 indicated that, in this year, with the aid of society funds, 2,799 ha of new field, and 2,239 ha of pasture and meadow had been cleared, 1,003,970 $\mathrm{m}$ of ditch dug, 97,279 loads of natural soil fertilizers hauled, 183,803 bags of fertilizers and 408,990 kg of concentrated feedstuffs bought, 17,949 agricultural machines of various descriptions purchased, 5,480 cows and 5,804 horses bought, 4,032 new living houses and 3,282 cattle-sheds built, etc. For purposes of this kind the credit societies, in 1948, granted a total of 39,920 loans, amounting to 2,589 million marks.

To complete these figures it may be mentioned that the loan claims of the cooperative credit society organisation in 1948 totalled 22,100 million marks, or considerably more than those of the leading commercial banks, and also more than the corresponding total for all savings banks. The percentage of the total deposits in all the financial institutions of Finland held by co-operative credit societies has recently been approx. 14. - Since 1917 the SOK co-operative retail societies also have collected deposits from their members. Nearly three-quarters of the retail societies in operation $h_{y}$ the end of 1948 had a savings bank. The deposits by that date totalled 1,400 million marks.

Any consideration of the significance of the co-operative movement to agriculture must also include the general agricultural instruction work carried out by both the Pellervo Society and the central associations. In the initial years of the co-operative movement the instructors of the Pellervo Society. in the course of their travels about the country, carried out the most varied instruction tasks, including work outside the sphere of the establishment and operation of co-operative societies. For instance, the Society's dairy instructors, again and again, were asked for advice on the improvement, feeding and tending of cattle; on the building of cattlesheds, etc. The Periodical "Pellervo», first regularly published in 1900 and still being issued, grew into a very effective organ in the work for the promotion of agriculture. Until 1920 this paper also appeared in a Swedish edition. "Pellervo", in fact, was originally intended to serve more the purposes of professional agriculture than of the co-operative movement, and until the beginning of the Period of Independence it was almost the only paper on agriculture.

Of the other publishing activity of the Pellervo Society, the publication of manuals and text-books on agriculture has played a considerable part, expecially in the 1940's. Valuable publications with a wide circulation have been issued e.g. on feeding and tending of cattle, on gardening and on rural building activities. With the agricultural instruction work carried on through the Periodical "Pellervo» and other agricultural literature is connected teaching imparted in the form of correspondence courses. The Pellervo Correspondence Institute, established in 1929, now 
runs about 100 different courses, of which 30 deal with purely agricultural subjects. A total of 6,300 persons have, since 1929, passed one of the agricultural courses of this Institute; hence the agricultural youth training has profited from this method too.

During the world-wide period of economic depression, in 1932, a special department, the Market Research Institute, was established in connection with the Pellervo Society. In the research it carried out the price trends of agricultural products and requisites figured importantly. For this purpose price data have been collected annually from central associations and local co-operative societies. The endeavour has been to ascertain the extent of the production and marketing of the various agricultural products, by quantities and values, also the use of the requisites, such as fertilisers and concentrated feedstuffs. In 1933-1934 the Institute carried out an extensive research into the extent of the debts in agriculture, based on material collected from approx. 80,000 farms. The investigation into the economy of small farms in 1937-1938 was extensive in its scope.

Also, by means of its legal advice bureau, the Pellervo Society aims at assisting not only co-operative societies but also their individual members. This department, established in 1916, which at present employs two lawyers, issues advice, verbally and in writing, on legal matters, makes out sales and purchase deeds and promissory notes, tenancy agreements and other documents, drafts applications for submission to various authorities, etc.

An advanced stage has been reached by Valio's work for the development of fodder cultivation and the general intensification of agriculture as a whole. The Valio Laboratory, established in 1917, immediately included in its programme, not only the analyses and inspections required by the central association and its member dairies, but also scientific research for the promotion of cattle breeding and dairying. This laboratory gradually developed into an extensive research institute, in which questions of biochemistry particularly were studied. In 1929, on Valio's initiative, a special foundation was established to carry out biochemical research. The Biochemical Research Institute, maintained by this foundation, has been able to render very valuable service to agriculture. The endeavour to reduce production costs for milk have led to Valio's paying special attention to the development of pasture economy and to increasing the manufacture of AIV Fodder. Valio's instruction work on cattle breeding and dairying makes use of two professional periodicals, "Karjantuote» and "Karjatalous» (9).

An account of the work carried out by the co-operative movement for the benefit of agriculture must include certain additional measures taken by the Pellervo Society. The interest taken by this Society, and particularly by its Chairman, Professor Gebbhard, in questions of agricultural policy, led to the establishment by the farmers of an economic policy organisation, Maataloustuottajain Keskusliitto (The Central Association of Agricultural Producers), in 1917. The Society has also done work of merit for the development of insurance in the rural districts, and the rural communes are indebted to it for the establishment of a central bureau, Maalaiskuntien Liitto (The Association of Rural Communes) in 1920. In 1902 the Society, 
together with the Agricultural Societies' Organisation, organised a temporary inspection board to study agricultural machines. This board was the predecessor of the present State Institute for Research into Agricultural Machines.

The above survey of the influence of the co-operative movement on Finnish agriculture, for various reasons, must remain sketchy and incomplete. In the past 50 years co-operative activities have been extended to a great number of different branches, and accordingly a general picture of their contribution to the rise and expansion of agricultural production has become more difficult of realisation. Statistical material too is defective in many respects. The information provided above, however, is likely to confirm the notion general in Finland, that the development of agriculture in the present century is in a very great measure the work of the cooperative movement.

\section{REFERENCES.}

When the source is not mentioned, the data in the paper are based on the following:

Pellervo (Agricultural Review published by the Pellervo Society), volumes 1899-1949. Helsinki.

Suomen Osuustoimintalehti (Scientific monthly on Co-operation published by the Pellervo-Society), volumes 1909-1949. Helsinki.

Suomen Osuustoimintaliike (Annual Reports of the Pellervo Society and the Certral Co-operative Associations), I-XL, 1899-1940. Helsinki.

Pellervo-Seuran vuosikertomukset (The Pellervo Society, Annual Reports) 1941-1948. Helsinki.

Osuustoiminnallisten keskusliikkeiden vuosikertomukset (Annual Reports of the Central Co-operative Associations) 1941-1948. Helsinki.

(1) Anon. 1915. Osuuskauppaliike meillä ja muualla. Tehtyjä erehdyksiä korjaamaan ja uusia välttämään. Pellervo, 16, p. $1-830$.

(2) —— 1930. Osuusliike Puutarhakeskus r.1. suoritustilassa. Suomen Osuustoimintalehti, 22. p. $1-629$.

(3) FAbritius, ERnst 1897. Muutamista keinoista maaseudulla vallitsevan koronkiskomisen ehkäisemiseksi. Esitelmiä Kansantaloudellisessa Yhdistyksessä, p. $224-231$. Porvoo.

(4) Gebhard, Hannes 1899. Maanviljelijäin yhteistoiminnasta ulkomailla, p. 1-500. Helsinki.

(5) —- 1903. Osuuskassojen Keskuslainarahasto O.Y. Pellervon vuosikirja II, p. 373-415. Helsinki.

(6) —— 1903. Muutamia havaintoja ja mietteitä yhteisostojen keskittämisen järjestämisestä. Ibid., p. $364-372$.

(7) Grotenfelt, Gösta 1897. Suomen maanviljelys, p. 1-328. Porvoo.

(8) Mannelin, Karl 1911. Finlands smörexport, p. 1-196. Helsingfors.

(9) Pitkänen, VÄrnö 1938. Valion toiminta karjataloustuotteiden viennin kehittäjänä. Valion työmailta, p. $38-86$, Helsinki.

(10) Pitkäniemi, F. M. 1947. Pilkkeitä muistojeni lokeroista. Karjatalous, 23. p. 347-377.

(11) Puro, Olavi H. 1927. Suomen kulutusosuustoiminnan vaiheet vuoteen 1917, p. 1-250. Helsinki.

(12) Rahola, Ilmari 1949. Osuustoiminnallisen karjakaupan uusi vaihe. Suomen Osuustoimintalehti, 41 , p. $193-248$.

(13) Rangell, J. W. 1934. Osuuskassojen Keskuslainarahasto-Osakeyhtiön syntyvaiheet. Hannes Gebhardin muisto, p. 109-128. Helsinki. 
(14) Salomaa, Santeri 1938. Valion toiminta juuston valmistuksen ja sen kaupan edistämiseksi. Valion työmailta, p. 87-105. Helsinki.

(15) Srmonen, Seppo 1949. Lypsykarjatalousvaltainen maataloudellinen tuotantojärjestelmä Suomessa, p. 1-239. Helsinki.

(16) - 1949. Pellervolaisen osuustoiminnan historia, p. 1-500. Helsinki.

(17) Sorninen, K. M. 1924. Eri aloilla toimivia osuuskuntia. Yhteiseltä taipaleelta, p. 276-281. Helsinki.

(18) Säntti, Jonni 1924. Suomen osuusmeijeriliikkeen kehitys ja merkitys. Ibid., p. 170-179. Helsinki.

(19) Tuominen, KaArlo I. 1934. Maataloudellisen osuustoimintaliikkeemme rakenne. Suomen Osuustoimintalehti, 26 , p. $1-548$.

(20) Hankkija Suomen maanviljelijäin liikejärjestönä 1905-1919, p. 1-135., 1920. Helsinki.

(21) Karjakunta r.1. 1919-1943, p. 1-101, 1944. Helsinki.

(22) Vientikunta Muna r.1. 1922-1946, p. 1-67, 1947. Helsinki.

(23) Keskusosuuskunta Labor r.1. 1898-1948, p. 1-83, 1948. Helsinki.

\author{
S E L OS T US.
}

\title{
OSUUSTOIMINNAN MERKITYS SUOMEN MAATALOUDELLE.
}

\section{Seppo Simonen.}

Pellervo-Seuran perustamisesta ja samalla koko osuustoimintaliikkeen alkamisesta Suomessa tuli v. 1949 kuluneeksi täsmälleen puoli vuosisataa. Tämä merkkitapaus antaa aiheen palauttaa mieleen osuustoiminnan suuren merkityksen maataloudelle.

On luonnollisesti mahdotonta yhtenäisin numeroin tai numerosarjoin osoittaa, missä määrin maataloustuotantomme laajentuminen ja monipuolistuminen kuluvalla vuosisadalla on ollut osuustoimintaliikkeen ansiota. Näin ollen on tyydyttävä yleisluontoisiin toteamuksiin, minkä lisäksi johtopäätöksiä voi tehdä osuuskuntien luku- ja jäsenmäärän sekä liikevaihdon, osuustoiminnallista tietä markkinoitujen maataloustuotteiden suhteellisen osuuden ym. perusteella. Pellervo-Seuran ja osuustoiminnallisten keskusliikkeiden vuosikymmenien kuluessa harjoittaman maataloudellisen neuvonnan merkitys on myös muistettava, samoin Pellervo-Seuran työ maanviljelijöiden talouspoliittisen järjestäytymisen edistämiseksi, vakuutusolojen kehittämiseksi, maatalouskoneiden tarkastuksen aikaansaamiseksi jne.

Kaikki nämä tekijät huomioiden voi täydellä syyllä sanoa, että maatalouden kehitys kuluvan vuosisadan aikana on ollut erittäin suuressa määrin osuustoiminnan ansiota. 